\title{
Biological properties of Endophytic Fungi
}

\author{
Venkatesan Sudha', Ramar Govindaraj ${ }^{2}$, Kathirvelu Baskar $^{1 *}$, Naif Abdullah Al-Dhabi ${ }^{3}$, \\ Veeramuthu Duraipandiyan ${ }^{3}$
}

\begin{abstract}
${ }^{I}$ Department of Ecotoxicology and Entomology, Bioscience Research Foundation, Porur, Chennai, Tamil Nadu, India. ${ }^{2}$ Entomology Research Institute; Loyola College; Chennai, Tamil Nadu, India. ${ }^{3}$ Department of Botany and Microbiology, Addiriya Chair for Environmental Studies, College of Science, King Saud University, P.O.Box.2455, Riyadh, 11451, Saudi Arabia.
\end{abstract}

\begin{abstract}
The endophytic fungus is have rich source of secondary metabolites which act as biological active agent in the higher plants. The fungal derivatives play vital part in human life and their compounds are the source of drug for cancer, microbial and viral diseases. The natural compounds from the endophytes acts as growth inhibitor of plant pathogenic organism. Endophytes are rich sources of natural products which are used in agriculture (plant growth and insecticidal), pharmaceutical industries and also used for phytoremediation.
\end{abstract}

Key words: Endophytic fungi, secondary metabolites, anticancer, Phytoremediation, Pest management

\section{INTRODUCTION}

The term 'endophytes' (Greek: endon-within; phyton- plant) was first coined by de Bary (1886). Endophytes relationship with plant varies from symbiotic to pathogenic. Endophytes benefit host plant by preventing pathogenic organism from colonizing. It has been categorized into two main groups (Clavicipitaceous and non-clavicipitaceous) based on differences in evolution, taxonomy, plants host and ecological functions. Clavicipitaceous are able to infect only some species of grasses and nonclavicipitaceous are found in the asymptomatic tissues of other higher plants (Rodriguez et al. 2008). It stimulates plants growth, increase disease resistance, improve the plants ability to withstand environmental stresses and recycle nutrients (Sturz et al. 2000). Endophytes are rich source of secondary metabolites with multifold importance (Strobel and Daisy 2003). Compare to other endophytic microorganisms, fungal endophytes produce large number of secondary activities (Zhang et al. 2006). Endophytes isolated from medicinal plants possess strong fungicidal, bactericidal and cytotoxic metabolites (Wang et al. 2007). It produce enzymes which are used for various application like degradation and biotransformation of organic compound (Firáková et al. 2007; Pimentel et al. 2011). The endophytes derivatives are used in biotechnological applications (Tomita 2003). It has a wide significance in pharmaceutical science because of its antimicrobial, anticancer and antiviral activities. (Selim et al. 2012).

\section{Anticancer activity}

*Authors for correspondence: suribaskar@hotmail.com 
Taxol is a highly functionalized diterpenoid which is widely used as anticancer drug (Wani et al. 1971). It was first isolated from the bark of western yew, Taxus brevifolia. During the cell division, taxol prevent the depolymerization of tubulin. Production of taxol from different genus of endophytes by fermentation is a cheaper method (Page et al. 1999). The anticancer drug, taxol has been found in many genera of endophytic fungi (Alternaria, Fusarium, Monochaetia, Pestalotia, Pestalotiopsis, Pithomyces and Taxomyces) (Strobel et al. 1996). More than 15 fungi genera were produced paclitaxel and its analogues (Zhao et al.2010).

Pandi et al. (2011) reported that taxol isolated from Lasiodiplodia theobromae showed activity against breast cancer cell line. Alternariol 9-methyl ether is a major mycotoxin produced by fungi of the genus Alternaria. It can induce mitochondrial apoptosis in human colon carcinoma cells, and induce DNA strand breaks, micronuclei and gene mutations in various cultured mammalian cells (Meng et al. 2012). Giridharan et al. (2012) reported that sclerotiorin isolated from Cephalotheca faveolata showed anti-proliferative activity against cancer cells and also it induces apoptosis in colon cancer cells. Extracts from endophytes, Fusarium sp., and Aspergillus fumigatus exhibited inhibitory activity against HeLa cervix cancer cell lines (Ruma et al. 2013). The endophytic fungi, A. terreus showed cytotoxic effect against HepG2 cancer cell line (Suja et al. 2014). Polyketide compounds produced by Phoma sp., had high inhibitory activity against murine leukemia cells (Santiago et al. 2014). The anticancer activity was noticed in ethyl acetate extract of Alternaria alternata against human breast cancer cell lines and it also showed good cytotoxicity (Arivudainambi et al. 2014). Chen et al (2015) reported that cytochalasins from endophytic fungi, Phoma mutirostrata exhibited moderate anticancer activity against SMMC-7721 (hepatocellular carcinoma cell line), SK-BR-3 (breast cancer cell line), PANC-1 (pancreatic cancer cell line), HL-60 (human myeloid leukemia cell line) and A-549 (lung cancer cell line).

\section{Antimicrobial activity}

World health problems caused by drug resistant bacteria and fungi are increasing. Many pathogenic microorganisms have developed resistance due to the misusage or long-term usage of the same class of antibiotics. Intensive search for newer and more effective antibiotics to deal with these problems is now underway. The isolation of novel secondary metabolites from the endophytes is a progressive research field (Huang et al. 2008). Fungal endophytes such as Phaeosphaeria avenaria, Leptosphaeria sp., Fusarium sp., $\quad P$. chrysanthemicola, Cladosporium sp., Cylindrocarpon sp., Saussurea involucrata, Fusarium solani, Cordyceps memorabilis, $P$. longicolla and Dothideomycete sp., are found to have antimicrobial activity against human pathogenic bacteria and fungi such as Micrococcus luteus, Enterococus shirae, Escherichia coli, Klebsiella pneumonia, Bacillus subtilis, Staphylococcus aureus, Shigella flexneri, $S$. epidermidis, Candida tropicalis, C. albicans, Cryptococcus neoformans, A. fumigatus and Salmonella typhi (Lv et al. 2010; Tayung et al. 2011; Rhoden et al. 2012). The Phomopsis sp., exhibited antimicrobial activity against $E$. coli, $K$. pneumoniae, B. subtilis, M. luteus and C. albicans (Jayanthi et al. 2011). Silva et al. (2011) reported that secondary metabolites of A. niger, Curvularia pallescens, Guignardia bidwelii, Paecilomyces variotii and Mycelia sterilia showed antibacterial activity against $S$. aureus, B. subtilis, Enterococcus faecalis, M. luteus, E. coli and Pseudomonas aeruginosa. Gibberella sp., exhibited the antimicrobial activity against $S$. aureus and $C$. neoformans (Liang et al. 2012). The extracts from Colletotrichum gloeosporioides and Chaetomium globosum exhibited antimicrobial activity against Mycobacterium tuberculosis, Gordonia terrae, $S$. aureus and E. coli (Bungihan et al. 2013). The extracts isolated from C. gloeosporioides showed antimicrobial activity against Streptococcus pyogenes and Enteroccocus faecalis (Nath et al. 2014). The extract from Diaporthe arengae showed antimicrobial activity against $S$. aureus and $B$. subtilis (Patil et al. 2014). The earlier research clearly shows that Endophytic fungi derived compounds are being used in the development of antimicrobial drug.

\section{Insecticidal activity}

Endophyti fungi can protect their host plants from pathogens and pests (Arnold et al. 2003). The foliar endophytes can reduce herbivory by producing alkaloids which are toxic to insects and vertebrates (Schardl 2001). Webber (1981) who was the first researcher to endophytic fungi, $P$. oblonga to protect elm trees against the beetle Physocnemum brevilineum. The endophtic fungi (Acremonium coenophialum) exhibited insecticidal activity against aphids (Rhopalosiphum padi, Schizaphis 
graminum) and milkweed bug (Oncopeltus fasciatus) (Johnson et al.1985). Cladosporium herbarum, A. alternata, Rhodotorula rubra, Epicoccum nigrum, Cryptococcus sp., Penicillium sp., Fusarium graminearum were act as protectants to plants from herbivores (Larran et al. 2002; dos santos et al. 2003). The different genera of entomopathogenic fungus of Acremonium, Beauveria, Cladosporium, Clonostachys and Paecilomyces; were isolated from the coffee plants, among them B. bassiana and Clonostachys rosea were pathogenic to coffee berry borer (Vega et al. 2008). B. bassiana was found to control the borer insects in coffee seedlings (Posada and Vega 2006). Baskar et al. (2012) stated that B. bassiana isolated from Puleny exhibited larvicidal and growth inhibitory activities against Spodoptera litura. The endophytic fungi Claviceps purpurea possess a significant insecticidal activity against $A$. gossypii Glover (Hemiptera:Aphididae) (Shi et al. 2013). Senthilkumar et al (2014) reported that phytochemicals such as Dodecanoic acid, ethylester, Phthalic acid, octyl 2- pentyl ester isolated from Phomopsis sp. are used as insecticide. The Cladosporium oxysporum showed insecticidal activity against $A$. fabae (Bensaci et al. 2015). The extracts from Emericella nidulans, A. oryzae, A. tamarii and $A$. versicolor were applied topically on $S$. litura larvae and found that all the fungus showed insecticidal activity; notably $A$. versicolor showed maximum insecticidal activity (Abraham et al. 2015).

\section{Plant growth stimulants}

Endophytes can actively or passively promote the plant growth through a variety of mechanisms, as endophytic metabolites provide a variety of fitness to host plants enhanced by increasing plant resistance to biotic and abiotic stresses, as well as enhance plant growth. Many endophytes are capable of solubilization of phosphate, enhance uptake of phosphorus (P), nitrogen fixation, production of siderophores, and plant hormones such as auxin, abscisins, ethylene, gibberellins, and indole acetic acid (IAA), which are important for plant growth regulations (Goodman et al. 1986; Barraquio et al. 1997; Malinowski et al. 1999; Zou et al. 1999; Malinowski and Belesky 2000; Boddey et al. 2003; Loiret et al. 2004, Sandhiya et al. 2005, Firáková et al. 2007). Gibberellic acid (GA) is a potent phytohormone, that regulates plant growth. Fungal endophyte, Cladosporium sphaerospermum from the plant, Glycine max (L) Merr. produce
GA3, GA4 and GA7. It induced plant growth in rice and soybean (Hamayun et al. 2009). A pestalotin analogue isolated from the Pestalotiopsis microspora exhibited significant gibberellin activity against Distylium chinense seeds and increase germination rate (85.56\%) (Li et al. 2015). The Fusarium tricinctum and A. alternata derivatives of indole acetic acid enhanced the plant growth (Khan et al. 2015).

\section{Crop protection}

Endophytic fungi are also capable of inducing resistance to diseases, and many mechanisms have been proposed for this resistance. The mechanisms of endophyte induced resistance are related to the nutritional status of the host, and to increase the fitness of plants by enhancing their tolerance to abiotic stress (Aguilar and Barea 1996). Endophytic fungi Cryptosporiopsis $c f$. quercina and Colletotrichum sp., are found effective against phytopathogens such as Rhizoctonia cerealis, Phytophthora capsici, Pyricularia oryzae, Gaeumannomyces graminis (Li et al. 2000; Lu et al. 2000).

\section{Phytoremediation}

It found to play an important role in the ecological community, with the aim of decreasing the spoilage of land and water caused by excessive toxic organic insecticide, environmental degradation, industrial sewage, poisonous gases and loss of biodiversity. Biological control using endophytes as a new efficient method is being widely used for environmental remediation, and killing insects or pathogens (Guo et al. 2008).

A novel application of endophytes in the area of phytoremediation (plant assisted removal of xenobiotics and heavy metals from the soil) (Ma et al. 2011). However, the success of phytoremediation depends upon microbes and plant ability to tolerate and accumulate high concentrations of pollutant, while yielding a large biomass. Due to the potential of microorganisms for bioaccumulation of heavy metals and other pollutants from environment or its enhancing plant growth and pollutant uptake from soil by plant through mobilization/immobilization of pollutant (Ma et al. 2011). Plants, Festuca arundinacea schreb. and $F$. pratensis Huds. are infected with endophytic fungi Neotyphodium coenophialum and $N$. uncinatum and uninfected plants are grown on petroleum contaminated soil. The endophyte infected plants had more shoot and root biomass 
when compare to the uninfected plants (Soleimani et al. 2010a). It proves that the endophytes play a major role in phytoremediation.

Endophytes may play indirect or direct role in phytoremediation process and degradation of environmental toxins, indirectly through enhancing plant growth having ability of phytoremediation and this accelerate phytoremediation process, or directly through degradation and/or accumulating pollutants by itself. Endophytes have a cryptic existence and one of their main role in the ecosystem are decomposers, as they are among the primary colonizers of dead plant tissues (Kumaresan and Suryanarayanan 2002; Oses et al. 2008). The Neotyphodium endophytes enhance the Cadmium tolerance activity in two plant species of Festuca arundinacea and $F$. pratensis when compared to non endophyte infected plants (Soleimani et al. 2010b). The fungal endophyte Penicillium funiculosum acts against the copper stress and enhances the plant growth; it can be used in bioremediation of pollution in cultivated area by stress mediating endophytes (Khan and Lee 2013).

\section{CONCLUSION}

Endophytic fungi have wide application in different fields. It has the potential to produce many bioactive compounds. The secondary metabolites produced by the endophytic fungi have the ability to act as biocontrol agent. Endophytic fungi isolated from the medicinal plants would be a promising source for many pharmaceutical ingredients. Plants are the major preliminary source for pharmaceutical drug products. Isolating a compound from the plants and large scale production of a product is expensive and time consuming. But endophytic fungi originated from medicinal plants have the capability to produce valuable compounds and can be easily cultured and large scale production is possible through fermentation process. In future the products from the endophytic fungi will be a cheap source for medical, agriculture and other industries. It is sure that the research on endophytic fungi will lead to isolate more novel compounds.

\section{ACKNOWLEDGEMENT}

The Project was full financially supported by king Saud University, through Vice Deanship of Research Chairs.

\section{REFERENCE}

Abraham S, Basukriadi A, Pawiroharsono S, Sjamsuridzal W. Insecticidal activity of ethyl acetate extracts from culture filtrates of mangrove fungal endophytes. Mycobiol. 2015; 43: 137-149.

Aguilar AC, Barea JM. Arbuscular mycorrhizas and biological control of soil-borne plant pathogens - an overview of the mechanisms involved. Mycorrhiza. 1996; 6: 457-464.

Arivudainambi USE, Kanugula AK, Kotamraju S, Karunakaran C, Rajendran A. Antibacterial effect of an extract of the endophytic fungus Alternaria alternata and its cytotoxic activity on MCF-7 and MDA MB-231 tumour cell lines. Biological Lett. 2014; 51: 7-17.

Arnold AE, Mejia LC, Kyllo D, Rojas EI, Maynard Z, Robbins N, Herre EA. Fungal endophytes limit pathogen damage in a tropical tree. Proc Natl Acad Sci. 2013; 100: 15649-15654.

Barraquio WL, Revilla L, Ladha JK. Isolation of endophytic diazotrophic bacteria from wetland rice. Plant Soil. 1997; 194: 15-24.

Baskar K, Raj GA, Mohan PM, Lingathurai S, Ambrose T, Muthu C. Larvicidal and growth inhibitory activities of entomopathogenic fungus, Beauveria bassiana against Asian army worm, Spodoptera litura Fab. (Lepidoptera: Noctuidae). J Entomol. 2012; 9: 155-162.

Bensaci OA, Daoud H, Lombarkia N, Rouabah K. Formulation of the endophytic fungus Cladosporium oxysporum Berk. \& M.A. Curtis, isolated from Euphorbia bupleuroides subsp. luteola, as a new biocontrol tool against the black bean aphid (Aphis fabae Scop.). J Plant Protect Res. 2015; 55: 80-87.

Boddey RM, Urquiaga S, Alves BJR, Reis V. Endophytic nitrogen fixation in sugarcane: present knowledge and future applications. Plant Soil. 2003; 252: 139-149.

Bungihan ME , Tan MA, Takayama H, dela Cruz TEE, Nonato MG. A new macrolide isolated from the endophytic fungus Colletotrichum sp., Philippine Sci Lett. 2013; 6: http://www.philsciletters.org/pdf/2013n1.8p7.pdf

Chen ZM, Chen HP, Li Y, Feng T, Liu JK. Cytochalasins from cultures of endophytic fungus Phoma multirostrata EA-12. The J Antibiot. 2015; 68: 23-26.

Devaraju R, Satish S. Endophytic Mycoflora of Mirabilis jalapa L. and Studies on Antimicrobial Activity of its Endophytic Fusarium sp. Asian J Exp Biol Sci. 2011; 2: 75-79

dos Santos RMG, Rodrigues-Fo E, Rocha WC, Teixeira MFS. Endophytic fungi from Melia azedarach. World J Microbiol Biotechnol. 2003; 19: 767-770.

Firáková S, Šturdíková M, Múčková M. Bioactive secondary metabolites produced by microorganisms associated with plants. Biologia. 2007; 62/3: 251-257.

Giridharan P, Verekar SA, Khanna A, Mishra PD, Deshmukh SK. Anticancer activity of sclerotiorin, 
isolated from an endophytic fungus Cephalotheca faveolata Yaguchi, Nishim. \& Udagawa. Ind J Exp Biol. 2012; 50: 464 - 468.

Goodman RN, Kiraly Z, Wood RKS. The Biochemistry and Physiology of Plant Disease. University of Missouri Press, Columbia USA. 1986;

Guo B, Wang Y, Sun X, Tang K. Bioactive Natural Products from Endophytes: A review. Appl Biochem Microbiol. 2008; 44: 136-142.

Hamayun M, Khan SA, Ahmad N,Tang D, Kang S, Na C, Sohn E, Hwang Y, Shin D, Lee B, Kim J, Lee I. Cladosporium sphaerospermum as a new plant growth- promoting endophyte from the roots of Glycine max (L.) Merr. World J Microbiol Biotechnol. 2009; 25: 627-632

Huang WY, Cai YZ, Hyde KD, Croke H, Sun M. Biodiversity of endophytic fungi associated with 29 traditional Chinese medicinal plants. Fungal Diversity. 2008; 33: 61-75.

Jayanthi G, Kamalraj S, Karthikeyan K, Muthumary J. Antimicrobial and antioxidant activity of the endophytic fungus Phomopsis sp. GJJM07 isolated from Mesua ferrea. Int J Curr Sci. 2011; 1: 85-90.

Johnson MC, Dahlman DL, Siegel MR, Bush LP, Latch GCM, Potter DA, Varney DR. Insect feeding deterrents in endophyte-infected tall fescue. Appl Environ Microbiol. 1985; 49: 568-571.

Khan AL, Lee IJ. Endophytic Penicillium funiculosum LHL06 secretes gibberellin that reprograms Glycine $\max$ L. growth during copper stress. BMC Plant Biol. 2013; 13: 86. http://www.biomedcentral.com/content/pdf/14712229-13-86.pdf

Khan AR, Ullah I, Waqas M, Shahzad R, Hong SJ, Park GS, Jung BK, Lee IJ, Shin JH. Plant growth-promoting potential of endophytic fungi isolated from Solanum nigrum leaves. World J Microbiol Biotechnol. 2015; 31: 1461-1466.

Kumaresan V, Suryanarayanan TS. Endophytic assemblages in young, mature and senescent leaves of Rhizophora apiculata: evidence for the role of endophytes in mangrove litter degradation. Fungal Diversity. 2002; 9: 81-91.

Larran S, Perelló A, Simo MR, Moreno V. Isolation and analysis of endophytic microorganisms in wheat (Triticum aestivum L.) leaves. World J Microbiol Biotechnol. 2002; 18: 683-686.

Li JY, Strobel G, Harper J, Lobkovsky E, Clardy J. Cryptocin, a potent tetramic acid antimycotic from the endophytic fungus Cryptosporiopsis cf. quercina. Org Lett. 2000; 2: 767-770.

Li X, Guo Z, Deng Z, Yang J, Zou K. A New $\alpha$-Pyrone Derivative from Endophytic Fungus Pestalotiopsis microspora. Rec Nat Prod. 2015; 9: 503-508.

Liang H, Xing Y, Chen J, Zhang D, Guo S, Wang C. Antimicrobial activities of endophytic fungi isolated from Ophiopogon japonicus (Liliaceae). BMC Com Alt
Med. 2012; 238

http://www.biomedcentral.com/1472-6882/12/238

Loiret FG, Ortega D, Kleiner P, Ortega R, Rodes R, Dong Z. A putative new endophytic nitrogen-fixing bacterium Pantoea sp. from sugarcane. J Appl Microbiol. 2004; 97: 504-511.

Lu H, Xou WX, Meng JC, Hu J, Tan RX. New bioactive metabolites produced by Colletotrichum sp., an endophytic fungus in Artemisia annua. Plant Sci. 2000;151: 67-73.

Lv Y, Zhang Y, Chen Y, Cui J, Xing Y, Li X, Guo S. Diversity and Antimicrobial Activity of Endophytic Fungi Associated with the Alpine Plant Saussurea involucrate. Biol Pharm Bull. 2010; 33: 1300-1306

Ma Y, Prasad MNV, Rajkumar M, Freitas H. Plant growth promoting rhizobacteria and endophytes accelerate phytoremediation of metalliferous soils. Biotechnol Adv. 2011; 29: 248-258.

Malinowski DP, Belesky DP. Adaptations of endophyteinfected cool-season grasses to environmental stresses: mechanisms of drought and mineral stress tolerance. Crop Science. 2000; 40: 923-940.

Malinowski DP, Brauer DK, Belesky DP. Neotyphodium coenophialum endophyte affects root morphology of tall fescue grown under phosphorus deficiency. $J$ Agronomy Crop Science. 1999; 183: 53-60.

Meng X, Mao Z, Lou J, Xu L, Zhong L, Peng Y, Zhou L, Wang M. Benzopyranones from the endophytic fungus Hyalodendriella sp. Ponipodef 12 and their bioactivities. Molecules. 2012; 17: 11303-11314.

Nath A, Pathak J, Joshi SR. Bioactivity assessment of endophytic fungi associated with Centella asiatica and Murraya koengi. J Appl Biol Biotechnol. 2014; 2: 6-11.

Oses R, Valenzuela S, Freer J, Sanfuentes E, Rodriguez J. Fungal endophytes in xylem of healthy chilean trees and their possible role in early wood decay. Fungal Diversity. 2008; 33: 77-86.

Page M, Landry N, Boissinot M, Halie MC, Harvey H, Gagne M. Bacterial mass production of taxanes and paclitaxel. US Patent No. WO 99/ 32651. 1999.

Pandi M, Kumaran RS, Choi YK, Kim HJ, Muthumary J. Isolation and detection of taxol, an anticancer drug produced from Lasiodiplodia theobromae, an endophytic fungus of the medicinal plant Morinda citrifolia. African J Biotechnol. 2011; 10:1428-1435.

Patil MP, Patil RH, Patil SG, Maheshwari VL. Endophytic Mycoflora of Indian medicinal plant, Terminalia arjuna and their biological activities, Int $J$ Biotechnol Wellness Ind. 2014; 3: 53-61.

Pimentel MR, Molina G, Dionísio AP, Junior MRM, Pastore GM. The Use of Endophytes to obtain bioactive compounds and their application in biotransformation process. Biotechnol Res Int. 2011: 1-11. http://dx.doi.org/10.4061/2011/576286

Posada F, Vega FE. Inoculation and colonization of coffee seedlings (Coffea arabica L.) with the fungal entomopathogen Beauveria bassiana (Ascomycota: Hypocreales), Mycoscience. 2006; 47: 284-289. 
Rodriguez RJ, White Jr JF, Arnold A E, Redman RS. Fungal endophytes: diversity and functional roles. New Phytolog. 2009; 182: 314-330.

Ruma K, Sunil K, Prakash HS. Antioxidant, antiinflammatory, antimicrobial and cytotoxic properties of fungal endophytes from Garcinia species. Int $J$ Pharm Pharm Sci. 2013; 5: 889-897.

Sandhiya GS, Sugitha TC, Balachandar D, Kumar K. Endophytic colonization and in planta nitrogen fixation by a diazotrophic Serratia sp. in rice. Indian J Exp Biol. 2005; 43: 802-807.

Santiago C, Sun L, Munro MHG, Santhanam J. Polyketide and benzopyran compounds of an endophytic fungus isolated from Cinnamomum mollissimum: biological activity and structure, Asian Pac J Trop Biomed, 2014; 4: 627-632.

Schardl CL. Epichloe festucae and related mutualistic symbionts of grasses. Fungal Genet Biol. 2001; 33: 69-82.

Selim KA, El-Beih AA, AbdEl-Rahman TM, El-Diwany AI. Biology of eEndophytic fFungi. Curr Res Environm Appl Mycol. 2012; Doi 10.5943/cream/2/1/3. 31-82.

Senthilkumar N, Murugesan S, Babu DS, Rajeshkannan C. GC-MS analysis of the extract of endophytic fungus, Phomopsis sp. isolated from tropical tree species of India, Tectona grandis L.,. Int J Innov Res Sci Eng Tech. 2014; 3:10176-10179.

Shi YW, Zhang X, Lou K. Isolation, characterization, and insecticidal activity of an endophyte of drunken horse grass, Achnatherum inebrians. J Insect Sci. 2013; 13:151. doi: 10.1673/031.013.15101.

Soleimani M, Afyuni M, Hajabbasi MA, Nourbaksh F, Sabzalian MR, Christensen JH. Phytoremediation of an aged petroleum contaminated soil using endophyte infected and non infected grasses. Chemosphere. 2010; 81: 1084-1090.

Soleimani M, Hajabbasi MA, Afyuni M, Mirlohi A, Borggaard OK, Holm PE. Effect of endophytic fungi on cadmium tolerance and bioaccumulation by Festuca arundinacea and Festuca pratensis. Int $J$ Phytoremediation. 2010; 12: 6, 535 - 549.

Strobel G, Daisy B. Bioprospecting for microbial endophytes and their natural products. Microbiol Mol Biol Rev. 2003; 67: 491-502.

Strobel G, Yang X, Sears J, Kramer R, Sidhu RS, Hess WM. Taxol from Pestalotiopsis microspora, an endophytic fungus of Taxus wallachiana. Microbiol. 1996; 142: 435-440.

Sturz AV, Nowak J. Endophytic communities of rhizobacteria and the strategies required to create yield enhancing associations with crops. Appl Soil Ecol. 2000; 15: 183-190.

Suja M, Vasuki S, Sajitha N. Anticancer activity of compounds isolated from marine endophytic fungus Aspergillus terreus. World J Pharm Pharm Sci. 2014; 3: 661-672.
Tayung K, Barik BP, Jha DK, Deka DC. Identification and characterization of antimicrobial metabolite from an endophytic fungus, Fusarium solani isolated from bark of Himalayan yew. Mycosphere. 2011; 2: 203213.

Tomita F. Endophytes in Southeast Asia and Japan: their taxonomic diversity and potential applications. Fungal Diversity. 2003; 14: 187-204.

Vega FE, Posada F, Aime MC, Pava-Ripoll M, Infante F, Rehner SA. Entomopathogenic fungal endophytes. Biological Control. 2008; 46: 72-82.

Wang FW, Jiao RH, Cheng AB, Tan SH, Song YC. Antimicrobial potentials of endophytic fungi residing in Quercus variabilis and brefeldin A obtained from Cladosporium sp. World J Microbiol Biotechnol. 2007; 23, 79-83.

Wani MC, Taylor HL, Wall ME, Coggon P, McPhail AT. Plant antitumor agents. VI. The isolation and structure of taxol, a novel antileukemic and antitumor agent from Taxus brevifolia. J Am Chem Soc. 1971; 93: 2325-2327. 
Webber J. A natural control of Dutch elm disease. Nature.1981; 292: 449-451.

Zhang HW, Song YC, Tan RX. Biology and chemistry of endophytes. Nat Prod Rep. 2006; 23: 753-771.

Zhao J, Zhou L, Wang J, Shan T, Zhong L, Liu X, Gao $\mathrm{X}$. Endophytic fungi for producing bioactive compounds originally from their host plants. Curr Res Technology Edu Top Appl Microbial Microbial Biotechnol. 2010; 567-576.

Received: December 08, 2015; Accepted: February 03, 2016. 